\title{
Mycobial deterioration of stone monuments of Dharmarajika, Taxila
}

\begin{abstract}
The microbial decay of stone monuments in many tropical countries has become a serious threat for their future existence. Present investigation was conducted to evaluate the status of mycobial decay of stone monuments of Dharmarajika. A total of nineteen fungal species belonging to thirteen genera were isolated from colored stains, patinas and biofilms produced on the surfaces of monuments due to mechanism of biodeterioration. The fungal species Alternaria alternata, Aspergillus fumigatus, Aspergillus flavus, Aspergillus niger, Cladosporium herbarum, Curvularia lunata, Dematium spp., Fusarium oxysporum, Mucor hiemalis, Penicillium chrysogenum, Penicillium frequentans and Rhizopus oryzae were prevalent. Some variations in the occurrence of fungal species were also recorded. The isolated fungal species were also analyzed for their organic acids production to understand the corrosive effects of their metabolic secretions on stone materials.
\end{abstract}

It was found that all prevalent fungal strains produced different organic acids including oxalic acids, citric acids, fumaric acid, acetic acid, gluconic acid and succinic acid.
Volume 2 Issue I - 2015

\author{
Muhammad Farooq,' Mukhtiar Hassan, ${ }^{2}$ \\ Farzana Gull2 \\ 'Department of Microbiology, Hazara University, Pakistan \\ ${ }^{2}$ Department of Biochemistry, Hazara University, Pakistan
}

Correspondence: Muhammad Farooq, Department of Microbiology, Hazara University, Mansehra, Pakistan, Tel 92-03315192637, Fax 92-0997-530046, Email farhum36@yahoo.com

Received: January II, 2015 | Published: March 03, 2015

Keywords: mycobial decay, Dharmarajika, biodeterioration, monuments, organic acids

Abbreviations: HPLC, high performance liquid chromatography; UNESCO, United Nations educational scientific and cultural organization; SID, serial identification

\section{Introduction}

The weathering and decay of cultural heritage is a complex process, which is caused by the interaction of many physical, chemical and biological agents. The different biological deteriogens such as bacteria, algae, cyanobacteria, bryophytes, mosses, fungi, insects, rodents, birds and human beings play a momentous role in the decay of historical monuments. The biological growth of microorganisms can cause staining, cracking, powdering, disfigurement and displacement of building material, which leads to the permanent loss of stone monuments. Such aesthetic damage is accompanied by the transformation of the chemical and mechanical properties of stone material and this causes the formation of surface patinas of different colors. $^{1,2}$

Among different biological agents, fungi play more dangerous role in the bio-deterioration of stone monuments because of their complex metabolic activities on stone surface. Many fungal species have been isolated from the stone monuments located in different countries. Species of Alternaria, Aspergillus, Acremonium, Arthobotrys, Auerobasidium, Cladosporium, Curvularia, Drechslera, Fusarium, Helminthosporium, Mucor, Phoma, Penicillium, Rhizopus, Trichothecium and Trichoderma have been reported as prevalent fungi involved in biological decay of stone monuments. The growth of these fungal genera on stone monuments was a cause of staining and structural decay of stone material of these monuments. ${ }^{3-8}$ Fungi produces many inorganic and organic acids during their metabolic activities on monuments. These acids cause mineral dissolution and change structural configuration of stone material. The organic acids such as oxalic, lactic and gluconic acids function as chelating agents and can demineralized a variety of stone substrates including calcium, silicon, iron, magnesium and manganese. ${ }^{9,10}$ The enzymes produce during metabolic activities of fungi are involved in transformation of complex and binding molecules of stone monuments into simple dissolvable molecules. ${ }^{11}$

Fungal metabolites can cause solubilization of cations and produce patinas of different mineralogical composition. The discoloration of monuments due to the formation of patinas is more havoc on light colored stone monuments. The interaction between fungal hyphae and stone substrate also causes the formation of biofilms with different colors and chemical compositions. The biodeterioration of binding material of stone monuments starts by uptake of calcium and then this action leaves the monumental surface eroded and exposed it to water and frost attack. ${ }^{12,13}$ The appearance of black crusts on lime stone monuments in two Spanish Cathedrals was studied. ${ }^{14}$ They found that Penicillium frequentans was associated with formation of black biofilms on the surface of these monuments. In an investigation it was found that black stain on stone monuments were due to Aspergillus sydowi and Stachybotrys artra. ${ }^{15}$ The fungal colonization of sand stone and granite from Antarctica revealed that Alternaria, Aspergillus, Auerobasidium, Candida, Cladosporium, Paecilomyces, Phoma, Penicillium and Sporobolomyces were found active in weathering of rock and stone monuments. ${ }^{16}$ The black fungi such as Phoma and Alternaria were found as deteriorating agent of marble and lime stone monuments. ${ }^{17}$ The study of different aspects of biodeterioration of monuments is always helpful for the proper preservation of this world heritage. The archaeological monuments of Taxila are under the threat of severe biological decay. Most monuments of Taxila have the signs of structural distress such as leans, bulges, displacement and fractures. The present investigation was carried out to understand the mechanism of biodeterioration of stone monuments of Taxila.

\section{Materials and methods}

\section{Study sites}

Dharmarajika Stupa is one of the eight shrines constructed in the $3^{\text {rd }}$ century $\mathrm{BC}$ during the reign of Emperor Ashoka of the Mauryan dynasty. It is earliest and largest Buddhist stupa in Taxila. The modern 
name of Dharmarajika is Chirtope. Dharmarajika is also famous for monastic quarters, stupas and chapels. The remains of Dharmarajika are a source of valuable data for history, local architecture and art of past times. The masonry of Dharmarajika remains is rough limestone rubble. The SID number of Dharmarajika as world heritage is 139-006 in UNESCO world heritage sites list. In present investigation fungal species were isolated from six monuments including Main central stupa of Dharmarajika, Figural decorated stupa, Wall of a small stupa, Buddhist stupa no. 12, Wall of stupa no.11, Chapel and Stupa no.13. The archaeological monuments of Dharmarajika are under the threat of biodeterioration (Figures 1-4).

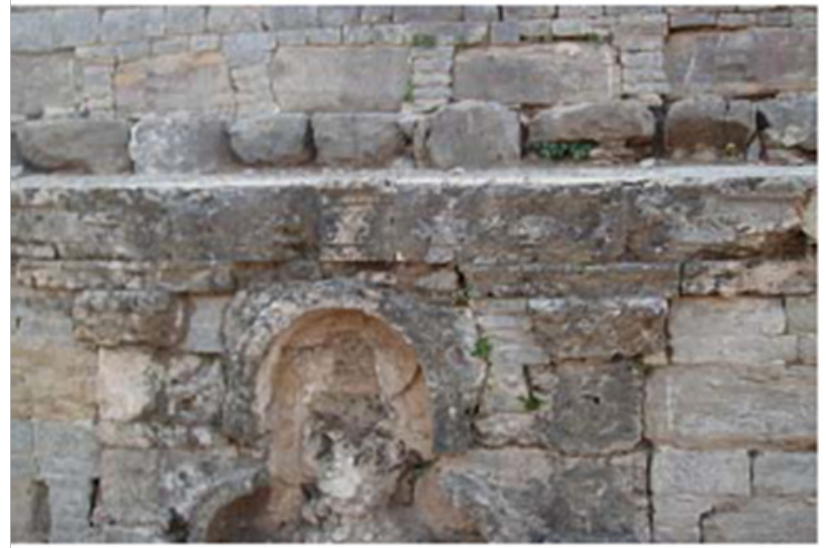

Figure I Wall of Stupa no. I I at Dharmarajika with heavy fungal growth.

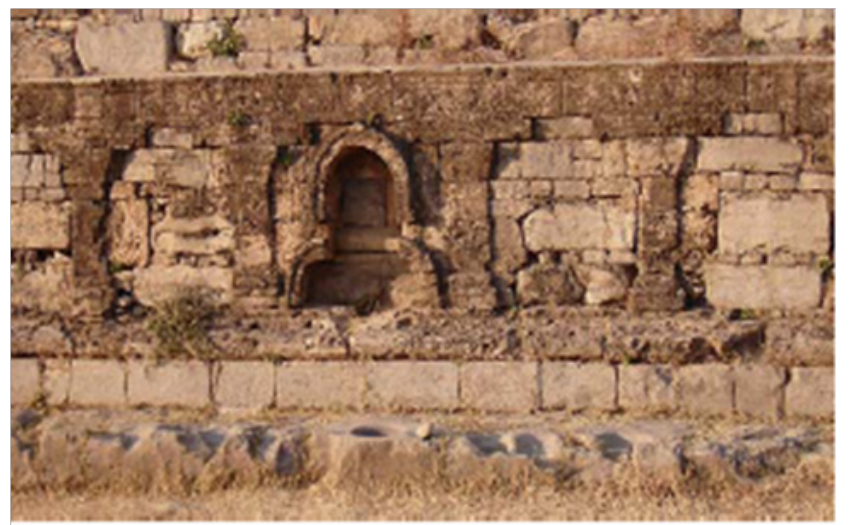

Figure 2 Wall of small stupa at Dharmarajika with thick fungal biofilm.

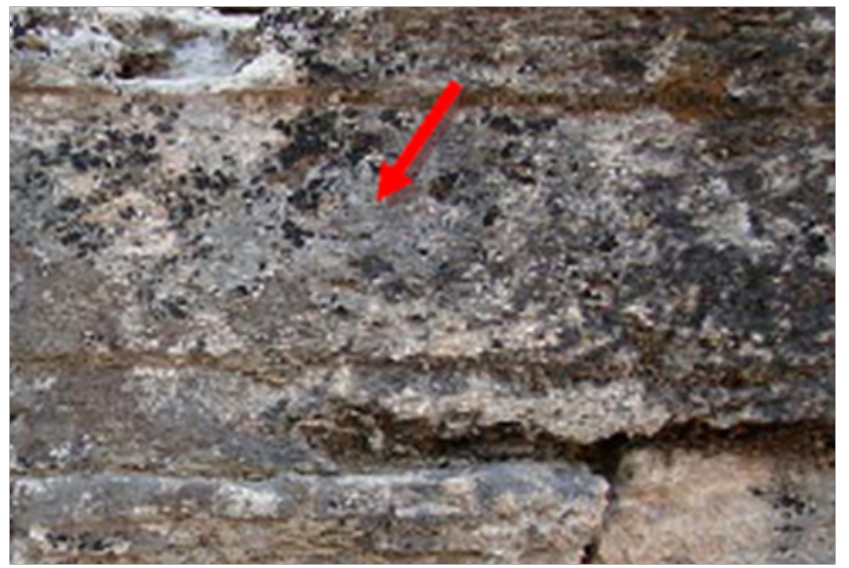

Figure 3 Thick and hard fungal stains.

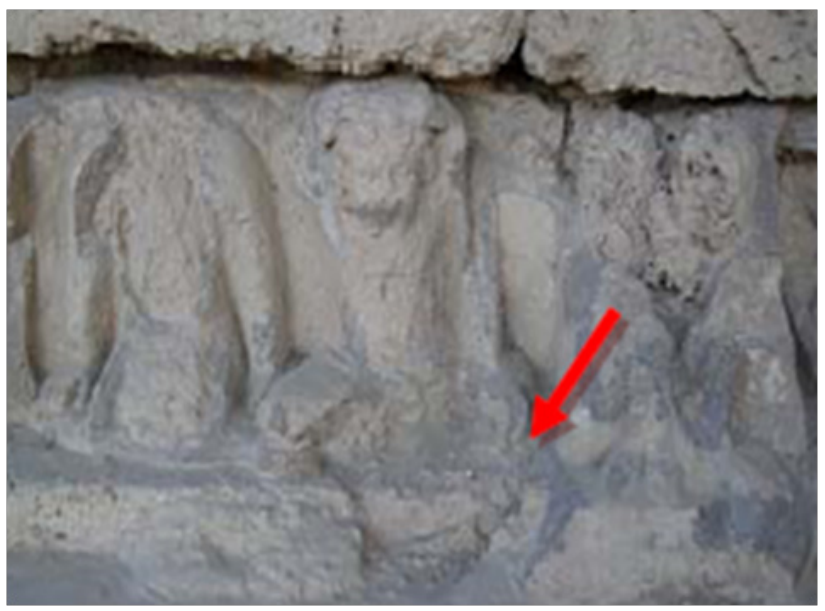

Figure 4 Colored patinas on the stupa.

\section{Isolation of stone mycoflora}

Sterile adhesive tape was used for the isolation of mycoflora from the surface of monuments. The hard and dried stains were removed by etching with the help of sterilized sticking tape and then these small pieces of tape were dispensed into Petri dishes or in test tubes slants containing culture media. Collection of sample was done by attaching of a strip of tape to the surface being sampled. Adhesive tape was pressed firmly on the surface of compact alternations. The tape was affixed on to a sterile glass slide and was stored in dark at $4^{\circ} \mathrm{C}$ for initial observation. The petri plates having sampling material were incubated at $25^{\circ} \mathrm{C} \pm 3^{\circ} \mathrm{C}$ for $8-10$ days and colonies were counted and isolated by digital colony counter.

\section{Identification of fungi}

The macro morphological and micro morphological features of taxonomic interest were studied at different microscopic powers i.e. $\mathrm{X} 10, \mathrm{X} 40$ and X100. The Identification of fungi was done with the help of reference works. ${ }^{18,19}$

\section{Organic acids determination by HPLC}

For the Determination of organic acids produced by isolated fungi Malt extract broth medium was used. Fungal strains were grown and multiplied in Malt extract broth medium with three replicates in each treatment. The purified solutions were prepared. On fifth day cultures were blended having three replicates of each culture. Blended cultures were centrifuged at $2000 \mathrm{rpm}$ for 20 minutes. Supernatant of each blended culture was filtered through $0.45 \mu \mathrm{m}$ non-sterile $4 \mathrm{~mm}$ sized micro filter syringes. Further purification was done by centrifugation of the filtered cultures (stored in up and off tip) in micro centrifuge.

The $20 \mu 1$ purified solutions of each culture was injected in bio-rad ion exchange column of Aminex 87-H (25*4.6 mm). The operating conditions consisted of $0.001 \mathrm{~N} \mathrm{H} 2 \mathrm{SO} 4$ the mobile phase at a constant (isocratic) flow rate of $0.6 \mathrm{ml} \mathrm{min}-1$ and column was operated at $25^{\circ} \mathrm{C}$. Organic acid concentrations in samples were determined with the help of RI detector. ${ }^{20}$ The software used during HPLC was a Turbochrome navigator system. RI impulse was read with the help of Turbochrome navigator programmer in $\mathrm{gI}-1$. The unknown organic acids in purified solution were determined by comparing the retention times and peak areas of chromatograms with the standards of oxalic acid, citric acid, gluconic acid, fumaric acid and acetic acid. 


\section{Results}

\section{Mycoflora of stone monuments}

Eighty sampling materials were isolated from the six stone monuments of Dharmarajika and 59 sampling material $(73.75 \%)$ showed the presence of fungi. Nineteen fungal species belonging to thirteen different genera were identified. The isolated fungi were Alternaria alternata, Alternaria solani, Aspergillus fumigatus, Aspergillus flavus, Aspergillus niger, Cladosporium herbarum, Cladosporium cladosporioides, Curvularia lunata, Dematium spp., Fusarium oxysporum, Fusarium culmorum, Geotrichum candidum, Helminthosporium solani, Mucor hiemalis, Penicillium chrysogenum, Penicillium frequentans, Phoma glomerations, Rhizopus oryzae and Trichoderma spp. ${ }^{21}$ The composition of fungal flora of six Archaeological sites of Dharmarajika is given in Table 1. The fungal species Alternaria alternata, Aspergillus fumigatus, Aspergillus flavus, Aspergillus niger, Cladosporium herbarum, Fusarium oxysporum, Mucor hiemalis, Penicillium chrysogenum, Penicillium frequentans, Rhizopus oryzae, Curvularia lunata and Dematium spp. were found as common and dominant fungal deteriogens of stone monuments of six archaeological sites of Dharmarajika, Taxila. These fungi were isolated from most of the sampling materials isolated from monuments. Some fungal species also showed variations in their occurrence. This variation is shown in Table 2.

Table I Composition of Fungal flora isolated from Archaeological sites of Dharmarajika

\begin{tabular}{|c|c|c|}
\hline $\begin{array}{l}\text { Serial } \\
\text { No }\end{array}$ & Fungal Genera & Fungal Species \\
\hline I & Alternaria & Alternaria alternata, Alternaria solani \\
\hline 2 & Aspergillus & $\begin{array}{l}\text { Aspergillus fumigatus, Aspergillus flavus, } \\
\text { Aspergillus niger }\end{array}$ \\
\hline 3 & Cladosporium & $\begin{array}{l}\text { Cladosporium herbarum, Cladosporium } \\
\text { cladosporioides }\end{array}$ \\
\hline 4 & Curvularia & Curvularia lunata \\
\hline 5 & Dematium & Dematium spp. \\
\hline 6 & Fusarium & Fusarium oxysporum, Fusarium culmorum \\
\hline 7 & Geotrichum & Geotrichum candidum, \\
\hline 8 & Helminthosporium & Helminthosporium solani \\
\hline 9 & Mucor & Mucor hiemalis \\
\hline 10 & Penicillium & $\begin{array}{l}\text { Penicillium chrysogenum, Penicillium } \\
\text { frequentans }\end{array}$ \\
\hline II & Phoma & Phoma glomerata \\
\hline 12 & Rhizopus & Rhizopus oryzae \\
\hline 13 & Trichoderma & Trichoderma spp. \\
\hline Total & 13 & 19 \\
\hline
\end{tabular}

Table 2 Variations in occurrence of fungal flora of archaeological sites of Dharmarajika

\begin{tabular}{|c|c|c|c|c|c|c|}
\hline Fungi & SI & S2 & $\mathbf{S 3}$ & S4 & S5 & S6 \\
\hline Alternaria alternata & + & + & + & + & + & + \\
\hline Alternaria solani & + & - & - & + & + & - \\
\hline Aspergillus fumigatus & + & + & + & + & + & + \\
\hline Aspergillus flavus & + & + & + & + & + & + \\
\hline Aspergillus niger & + & + & + & + & + & + \\
\hline Cladosporium herbarum & + & + & + & + & + & + \\
\hline Cladosporium cladosporioides & - & - & + & - & - & + \\
\hline Curvularia lunata & + & + & + & + & + & + \\
\hline Dematium spp. & + & + & - & + & + & + \\
\hline Fusarium oxysporum & + & + & + & + & + & + \\
\hline Fusarium culmorum & + & - & + & - & - & - \\
\hline Geotrichum candidum & + & + & - & - & - & + \\
\hline Helminthosporium solani & - & - & + & + & + & + \\
\hline Mucor hiemalis & + & + & + & + & + & + \\
\hline Penicillium chrysogenum & + & + & + & + & + & + \\
\hline Penicillium frequentans & + & + & - & + & + & + \\
\hline Phoma glomerata & & & & - & - & - \\
\hline Rhizopus oryzae & + & + & + & + & + & + \\
\hline Trichoderma spp & - & + & - & + & - & + \\
\hline
\end{tabular}

\section{Organic acids of isolated fungal species}

The organic acid produced buy fungal isolates in broth medium were analyzed. The results indicated that the highest acid producing strains were Aspergillus niger, Aspergillus flavus, Fusarium oxysporum, Mucor hiemalis, Penicillium frequentans, Penicillium chrysogenum, Trichoderma spp. and Rhizopus oryzae. The lowest acid producing fungi were Alternaria alternata, Cladosporium herbarum, Curvularia lunata and Cladosporium cladosporioides. Most common acids produced by the fungal strains in broth medium wee citric acid, oxalic acid, gluconic acid, succinic acid, fumaric acid and acetic acid. The lowest and highest values of these acids recorded are shown in Table 3. 
Table 3 Organic acids produced by fungi in broth medium $(\mathrm{g} / \mathrm{L})$

\begin{tabular}{|c|c|c|c|c|c|c|c|}
\hline Fungi & Total acids & Oxalic acid & Citric acid & Gluconic acid & Fumaric acid & Succinic acid & Acetic acid \\
\hline Alternaria alternata & 0.409 & 0.409 & & & & & \\
\hline Aspergillus niger & 1.76 & 0.76 & 0.53 & 0.04 & 0.25 & 0.18 & \\
\hline Aspergillus flavus & 0.71 & 0.21 & 0.14 & 0.12 & & 0.24 & \\
\hline Aspergillus fumigates & 0.98 & 0.41 & 0.32 & 0.11 & & 0.14 & \\
\hline Cladosporium herbarum & 0.7 & 0.47 & 0.23 & & & & \\
\hline Dematium spp. & 0.77 & 0.32 & 0.45 & & & & \\
\hline Fusarium oxysporum & 0.99 & 0.52 & 0.21 & & & & 0.26 \\
\hline Mucor hiemalis & 0.86 & 0.49 & 0.24 & 0.13 & & & \\
\hline Penicillium chrysogenum & 1.45 & 0.4 & 0.24 & & 0.38 & & 0.27 \\
\hline Penicillium frequentans & 1.02 & 0.36 & 0.21 & & 0.28 & & 0.17 \\
\hline Rhizopus oryzae & 0.46 & 0.31 & 0.15 & & & & \\
\hline Curvularia lunata & 0.12 & 0.12 & & & & & \\
\hline
\end{tabular}

\section{Discussion}

Biodeterioration of archaeological monuments due to fungi has also been studied in different countries and according to the prevailing climatic conditions and related physico-chemical factors, varied genera have been reported to be dominating. The fungal genera Alternaria, Aspergillus, Acremonium, Cladosporium, Curvularia, Dematium, Helminthosporium, Mucor, Penicillium, Phoma, Rhizopus, Fusarium and Trichoderma isolated in present study were also encountered in the findings of many previous investigations carried out in different parts of the world. ${ }^{22}$ The investigations from other countries showed almost the same genera as prevalent fungi active as biological agents in weathering of many monuments. In china the fungal strains Penicillium, Aspergillus, Cladosporium and Alternaria as dominant fungal genera during his research on the biodeterioration of Chinese Tong Tomb. ${ }^{4}$ Forty-five fungi from Japanese paintings and he reported Aspergillus, Trichoderma, Cladosporium and Fusarium as deteriorating agents of Japanese paintings. ${ }^{6}$ In Poland a research was conducted to isolate fungi from old ruins. He encountered Alternaria alternata, Aspergillus fumigatus, Cladosporium herbarum, Fusarium solani, Chyrosporium pamnorum, Cunninghaemella elegans, Epicocum purpurascens, Fusarium culmorum, Fusarium equistei, Monocillium indium, Mortierella acaminata, Penicillium cyclopium, Penicillium martesic and Tririraxhium soseum as dominant fungi. ${ }^{23}$

The analysis of chromatograms obtained by HPLC analysis also indicated different concentrations of glucose used as carbon source for the production of organic acids. The presence of organic and inorganic residues on mineral surface or within cracks and fissures can encourage the growth of fungi. It also proliferate on the waste products of algae and bacteria, dead cells and decaying plant material, dust particles, aerosol and animal faeces. ${ }^{24}$ The isolated fungal strains and their organic acids clearly indicated the mechanism of patinas and stains formation on the surface of archaeological monuments of Dharmarajika. The organic acids analysis in the present investigation can be correlate with the formation of different colored hard stains on lime stone based monuments of Taxila as previously it has been revealed that colored patinas are formed on the surface of stone monuments due to the formation of oxalate films. These patinas are more noticeable on light colored stone monuments. The formation of yellow, brown and red patinas on marble buildings and monuments has been studied in Italy. The chemical composition of these patinas was calcium oxalate. ${ }^{25}$ The Oxalic acid is considered as one of the most common acid exerted by fungi. This acid is involved in the formation of calcium oxalate films in the forms of whewellite and weddellite minerals. ${ }^{26}$ Fungi can also form other metallic oxalates with different metals and metal bearing minerals like cadmium, cobalt, copper, zinc and nickel. The precipitation of carbonates on fungal hyphae particularly calcite occurs in form of calcareous salts on the surface of lime stone. ${ }^{27}$

Weathering of stone monuments is based on many physical, chemical and biological processes which includes dissolution of carbonates and sulfates, solubilization by leaching elements from silicates, carbonates etc. weathering due to crystallization and hydration pressure microbial attack by inorganic and organic acids..$^{25}$ The study of fungal deterioration of archaeological monuments is significant. It helps not only to understand the effects of rapidly changing environmental conditions on the monuments but also helpful to find out the process of physical and chemical weathering of monuments. The importance of such studies has taken priorities in many European countries. In last decades many effective researches on different aspects of biodeterioration have been carried out in different regions of the world. The results of such investigations revealed that most of the world fame archaeological monuments are under severe biodeterioration especially in tropical countries like Pakistan due to changing environmental conditions, air pollution, industrialization, general negligence and so many other factors.

\section{Conclusion}

The results of present investigations revealed that the stone monuments of world fame archaeological sites of Taxila are under the severe biodeterioration. The fungal species isolated from the surface of monuments are found biodeteriogens as many thick biofilms, hard colored stains and patinas are very frequent on these monuments. The presence of some fungal species like Alternaria, Aspergillus, Cladosporium, Rhizopus and Penicillium can cause many 
aesthetical damages of world fame archaeological remains of Taxila because these fungi have been reported as biodeteriogens of cultural heritage especially stone based monuments. The stone monuments of Taxila are a sign of human civilization and concerned with Gandhara civilization so it is very important to preserve these world heritage for coming generation. The conservation authorities are recommended to take prompt action to eradicate fungal species from these monuments and also take preventive methods to avoid any future mechanism of decay.

\section{Acknowledgments}

The authors are very thankful to Director General, Department of Archaeology, Government of Pakistan for providing facilities during this research project.

\section{Conflicts of interest}

Authors declare that there is no conflict of interest.

\section{References}

1. Wainwright INM. Lichen removal from an engraved memorial to Walt Whitman. Association for preservation Technology Bulletin. 1986;18(4):46-51

2. Griffin PS, Indicator N, Koestler RJ. The biodeterioration of stone: A Review of deterioration mechanisms, conservation case histories and treatment. International Biodeterioration. 1991;28(1-4):187-207.

3. Rebricova NI. Some ecological aspects of protection of Old Russian paintings from microbiological deterioration. Proceedings of the International conference on biodeterioration of cultural property: India; 1989. 294-306 p.

4. Xie W. Identification and Preservation of mould on the frescoes from Chinese Tong tomb. Proceeding of the EEC China workshop on preservation of cultural heritage: China; 1992. 431-438 p

5. Gorbushina AA, Krumbein WE, Hamman $\mathrm{CH}$, et al. Role of black fungi on color change and biodeterioration of antique marbles. Taylor \& Francis CRC Press: Spain; 1993. 205-221 p.

6. Koyano M. Fungal contamination of Japanese painting stored in Japan. Proceedings of the $2^{\text {nd }}$ International Conference, Biodeterioration of Cultural property: Japan; 1993. 570-581 p.

7. Arai H. Foxing caused by fungi. Twenty five years of study. International Biodeterioration \& Biodegradation. 2000;46(3):181-188.

8. Strzelczyk AB. Observation on aesthetic and structural changes induced in Polish historic objects by microorganisms. International Biodeterioration \& Biodegradation. 2004;53(3):151-156.

9. Juroczkin J, Bode K, Petersen K, et al. Some physiological characteristics of fungi isolated from sandstone. Proceedings of the $5^{\text {th }}$ International Congress on Deterioration and Conservation of Stone: Poland; 1988. 21-25 p.

10. Petersen K, Grote G, Krumbein WE. Biotransfer of metals by fungi isolated from rock. In: Proceedings of the $5^{\text {th }}$ International Congress on Deterioration and Conservation of stone: Poland; 1988a. 111-119 p.
11. Maria PDB, Maddalena DG, Paola C, et al. Microbial formation of oxalate films on monuments surface: Bioprotection or biodeterioration. Geomicrobiology Journal. 1999;16(1):55-64.

12. Martino E, Pandi L, Fenoglio I, et al. Soil fungal hyphae bind and attack asbestos fibers. Angew Chem Int Ed Engl. 2003;42(2):219-222.

13. Garcia-Valles M, Urzi C, De Leo F, et al. Biological weathering and mineral deposits of the Belevi marble quarry (Ephesus, Turkey). International Biodeterioration \& Biodegradation. 2000;46(3):221-227.

14. De-la-Torre MA, Gomez Alarcon G, Vazcaino C, et al. Biochemical mechanisms of stone alteration carried out by filamentous fungi living in monuments. Biogeochemistry. 1993;19:129-147.

15. Saiz-Jimenez C. Microbial melanins in stone monuments. Science of the Total Environment. 1995;167(1-3):273-286.

16. Hirsch P, Eckhardt FEW, Palmer RJJ. Fungi active in weathering of rock and stone monuments. Canadian Journal of Botany. 1995;73(S1):1384-1390.

17. Diakumaku E, Ausset P, Sterflinger K, et al. On the problem of rock blackening by fly ash, fungal and other biogenic particles and their detection in Mediterranean marbles and monuments. Proceedings of the $3^{\text {rd }}$ International Symposium: Italy; 1994. 305-310 p.

18. Cooke WB. A laboratory guide to fungi in polluted waters, sewage, and sewage treatment systems; their identification and culture. Public Health Service: Cincinnati, USA; 1963.

19. Nilson S. Atlas of Airborne fungal spores in Europe. Springer-Verlog Germany; 1983.

20. Lopez FF, Gomez EF. Simultaneous determination of the major organic acids, sugars, glycol and ethanol by HPLC in Grape musts and white wines. Journal of Chromatographic Science. 1996;34(5):254-257.

21. Kigwa R, Arai H. Identification report. Filamentous fungi isolated from various kinds of materials of cultural property. Science for conservation. 1995;34:8-12.

22. Kwsana H. Mukoflora wystepujaea nazaprawie gipsowej ruin zespolu palacowego Wlednigorze. Ochrona Zabytkov. 1995;48:97-100.

23. Sterflinger K. Fungi as geologic agents. Geomicrobiology Journal. 2000;17:97-124.

24. Tiano P. Biodeterioration of Monumental rocks: decay mechanisms and control methods. Science and technology for cultural heritage. 1998;7(2):19-38.

25. Monte M. Oxalate film formation on marble specimen caused by fungus Journal of Cultural Heritage. 2003;4(3):255-258.

26. Wilson MJ, Jones D, McHardy WJ. The weathering of serpentinite by Lecanora atra. Lichenologist. 1981;13(2):167-176.

27. Bruand A, Duval O. Calcified fungal filaments in the petrocalcic horizon of Eutrochreptsin Beavce, France. Soil Science Society of America Journal. 1999;63:164-169. 